\title{
Wildlife trade in Brazil: A closer look at wild pets welfare issues
}

\author{
Kuhnen, $V V^{a *}$ and Kanaan, $V T^{b}$ \\ ${ }^{a}$ Laboratório de Ecologia de Mamíferos, Departamento de Biologia Animal, Universidade Estadual de Campinas - Unicamp, \\ Rua Monteiro Lobato, 255, Cidade Universitária Zeferino Vaz, CEP 13083-970, Campinas, SP, Brazil

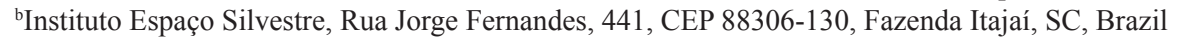 \\ *e-mail: vanessavk@ig.com.br
}

Received: August 30, 2012 - Accepted: December 5, 2012 - Distributed: February 28, 2014

\begin{abstract}
Wild animals have been kept as pets for centuries, in Brazil companionship is one of the main reasons why wild species are legally bred and traded. This paper is an attempt to call the attention for problems concerning the welfare of wild pets involved in the trading system in Brazil. Some issues presented are: a) the significant increase in the number of wildlife breeders and traders and the difficulties faced by of the Brazilian government in controlling this activity; b) the main welfare issues faced by breeders and owners of wild pets; and c) the destination of wild pets no longer wanted. Finally, some recommendations are made having the welfare of the animals as a priority.
\end{abstract}

Keywords: well-being, captivity, wild pets, wildlife trade, wildlife breeding.

\section{Comércio de animais silvestres no Brasil: Um olhar atento aos problemas de bem-estar animal}

\begin{abstract}
Resumo
Animais silvestres têm sido mantidos como animais de estimação por séculos, no Brasil as espécies silvestres são legalmente criadas e comercializadas principalmente para esta finalidade. Este trabalho é uma chamada de atenção para os problemas relativos ao bem-estar dos animais silvestres criados e comercializados no Brasil. Algumas questões apresentadas são: a) o aumento significativo do número de criadores e comerciantes de animais silvestres, e as dificuldades enfrentadas pelo governo brasileiro para controlar essa atividade; b) as falhas e dificuldades enfrentadas pelos criadores e proprietários para oferecer um bem-estar à espécies silvestres; e c) a problemática da destinação dos animais que não são mais de interesse para os proprietários. Finalmente, algumas recomendações são feitas visando o bem-estar animal como prioridade.
\end{abstract}

Palavras-chave: cativeiro, animais de estimação, criação de animais silvestres.

\section{Introduction}

In Brazil, several species of wild animals and their products are sold for different purposes such as food, medicinal, magic religious rituals, ornaments and companionship (Alves and Pereira Filho 2007; Alves and Rosa, 2010; Alves et al., 2012, 2013; Dias et al., 2011; Rosa et al., 2011; Kuhnen et al., 2012). Wild animals have been kept for companionship for centuries, it is currently one of the most popular hobbies in the world and the demand is increasing every year (Carrete \& Tella, 2008). For example, over one million exotic birds are legally traded around the world on an annual basis (Gilardi, 2006). In Brazil the purposes of companionship represents the majority of wild species legally trade (Kuhnen et al., 2012; Alves et al., 2012).

Given this scenario, the aim of this paper is to present some issues related to the welfare of wild animals legally bred and traded in Brazil for the pet market. We will

start discussing the difficulties faced by the Brazilian government to control this activity and to ensure animal welfare policies; then we will present the main welfare issues faced by breeders and owners of wild pets; and finally we will discuss the destination wild pets which are no longer wanted and its impact on Brazilian biodiversity.

\section{Government Weakness}

The demand for wild animals to be kept as pets encourages wildlife trafficking in the world (RENCTAS, 2001). The legalization of breeding wild animals in captivity is a controversial issue that has been discussed by opposing currents. One line of reasoning defends that legalization is a tool to combat traffic, as it gives the public a legal alternative to acquire a wild companion animal. On the other hand, it is argued that illegal trading is greater as legalized breeders may have an effectively participation 
by using illegally-acquired wild animals to increase and diversify their founder stock (Gonçalves and Regalado, 2007; Gama and Sassi, 2008). Also, illegally wild caught animals may go unnoticed because of the general lack of logistic support of the institutions that are in charge of inspections.

In Brazil, wildlife trade has been regulated by the Brazilian Institute of Environment and Renewable Natural Resources (IBAMA) which only allows for the commerce of specimens bred by legalized breeders. In 2004, there were about 700 wildlife commercial breeders in Brazil (IBAMA, 2004), while in 2010, this number nearly doubled in some states (Kuhnen et al., 2012). For each Brazilian state there is an Wildlife Center responsible for the management, licensing and inspection of all categories of breeders, traders and zoos. However, most centers struggle with the low number of employees, lack of technical knowledge, unavailability of cars and fuel for the inspections (Padrone, 2004).

In view of the difficulties faced by the government, inspections at the commercial breeding and trading establishments are insufficient to fight the illegal trade (through the falsification of bird rings and documents) in legalized establishments (Alves et al., 2010) and ensure the welfare of the animals in captivity. As part of the IBAMA licensing process all facilities are inspected, but once the license is given the monitoring is done through annual written reports on the number of animals that entered and left the stock. Although the exact numbers are unknown at the present time, many of the reports submitted have inaccurate data, incomplete or dubious information and not all facilities submit their annual reports regularly (Kuhnen et al., 2012). In general, inspections at licensed facilities are only done in case of complaint. Consequently any changes, such as in the diet, enclosures or hygiene routine, are often overlooked. With so few inspections it is difficult to evaluate the welfare of wild animals in captivity.

\section{Welfare Issues from the Breeder to the Owner}

The welfare of companion wild animals depends on several factors varying from the care provided by the breeders up to the care provided by their owners. According to IBAMA (2010) every commercial breeder must have the technical assistance of a biologist or veterinarian. However, there is a lack of specialized professionals available. It is not uncommon for the responsible biologist or veterinarian to work a few hours a week per facility and to be most in charge of the bureaucratic work required by the government agencies. Consequently the animal management is in fact done by the facility owner, whose priorities may not be the well-being of each animal, or by the caretaker who do not always have the technical knowledge needed. As there is no formal veterinary reporting system to track the incidence of injuries it is impossible to determine their frequency and some injuries may go untreated by the owner. Although the occurrence of these facts are informally known by those working in the field, the lack of reported data on the breeder/trader protocols and procedures makes it hard to determine whether or not animals are receiving appropriate care while in captivity.

In order not to compromise animal welfare, the owner of wild pets must be aware of their needs and meet them. Distress in captive animals may be due in part to physical and behavioural restrictions imposed by standard captive environments (Graham, 1998). Studies suggest that changes in the captive environment (cage size, enrichment, socialization) can improve the welfare of captive animals, however such changes require that the owner has sufficient knowledge, resources and motivation to fulfill these requisites throughout the life of the animal (Engebretson, 2006).

The difficulty in finding technical information may be due to the fact that there is very little literature available on the methods of reproductive, feeding, behavioral and housing management that will adequately meet the needs of the diversity of wild species allowed to be bred in Brazil. The literature available is mainly directed to the most popular bird orders, such as Psittaciformes and Passeriformes (see: Allgayer \& Cziulik, 2007), and mammals bred for the meat market (see: Lopes et al., 2004, Nogueira et al., 2010). In addition, the Brazilian Law $n^{\circ} .9605 / 1998$ that refers to the crimes against fauna is vague and does not address the 'five freedoms' (FAWC 1992) or provide any other information regarding animal well-being, especially about captive wild animals in Brazil.

\section{Wild Pets no Longer Wanted and their Destination}

The lack of interest or commitment in providing specialized care for a long-lived species may contribute to wild animal pets being abandoned at some point in their lives. For instance, as animals mature, they may start displaying unwanted behaviors and become undesirable by their owners. Despite the fact that captive wild animals destination are regulated (IBAMA Instrução Normativa $\mathrm{n}^{\circ} 179$ ), many owners do not look for, or even know about the existence of licensed Wildlife Screening Centers (CETAS) or other solutions. Thus, many animals are abandoned, even though they might be exotic species, may not be fit to live in the wild on their own, or may impact the natural local populations by introducing diseases or becoming nuisance animals. Some examples are the marmoset Callithrix jacchus original from the Northeast of Brazil which is now found in the whole Brazilian territory (Morais et al., 2008) and the exotic turtle Trachemys scripta elegans (Ferronato et al., 2009).

For those animals taken to the CETAS there are some possible outcomes, for example: they can be euthanized, sent to IBAMA licensed breeding facilities, universities or to zoos, or released back into the wild following specific guidelines (IBAMA Normative Instruction $\mathrm{n}^{\circ} 179$ and Planos de Ação Nacional- ICMBio). Despite the existence of instructions in the Brazilian law (Instruções Normativas) regarding release programs that recommend 
expensive procedures that require specialized knowledge, many animals are released with no behavioral and physical criteria and/or monitoring (personal observation). Many animals with release potential are not released, but instead are transferred to breeders, zoos or universities. In many cases, breeders and zoos do not have enough room to receive all animals apprehended. Consequently, animals may be kept at the CETAS for long periods of time. Since CETAS are screening facilities, they are not structured to keep animals for long. There are not enough enclosures that meet the basic needs of all of the species admitted and some of the facilities do not have a quarantine room, or species-specific enclosures. The financial problem also exists, with a lack of financial resources potentially limiting the supply of food and medication when it is needed. With these difficulties, it is hard to meet the minimum welfare standard for the animals.

\section{Final Considerations}

The Brazilian government needs to invest in managing, inspecting and monitoring the wildlife trade. In addition to breeders/traders, caretakers should also be monitored, since there are no minimum standards to keep a wild animal as a companion. Given the financial limitations, Brazilian government partnerships with private and/or non-profit organizations could be established to ensure that the lack of resources does not result in activities that may affect wild animal welfare. The public needs to be educated about the current wildlife trade situation in Brazil. Recently, national campaigns from the World Society for the Protection of Animals - Brazil (WSPA-Brasil) and IBAMA aimed to educate the public about the responsibility that comes with having a wild species as a pet and issues related to wildlife traffic, respectively. Other campaigns are needed to reach the rural populations, promoting alternatives between socioeconomic and conservation interests, such as ecological tourism. Educational material could also be distributed to the caretakers of wild animals for companionship with information about the biology and requirements of the specie purchased.

Given the magnitude of Brazil and the problems described in the present paper it is crucial to improve ways to assess the welfare of wild animals in captivity. Some options for the management of wildlife-keeping activities include law enforcement and environmental education (Alves et al., 2010). Also, the creation of a centered database with information about the state of animals apprehended and those kept at CETAS, breeders/traders and caretakers. Further research is necessary to gain a better understanding on current scenario of the welfare of captive wild animals.

Therefore, finding ways to replace the demand for wild species as pets with a demand for preserving the species in the wild may be the best way to reduce captive welfare problems and ensure the welfare of animals and the environment. The present work itself is an attempt to call the attention for all persistent problems concerning the welfare of wild animals involved in the trading system in Brazil, and contribute to change the current scenario. In addition to conservation strategies, it is crucial that the welfare of the animals be considered a priority as well.

\section{References}

ALLGAYER, MC. and CZIULIK, M., 2007. Reprodução de psitacídeos em cativeiro. Revista Brasileira de Reprodução Animal, vol. 31, no. 3, p. 344-350.

ALVES, RRN. and PEREIRA FILHO, GA., 2007. Commercialization and use of snakes in North and Northeastern Brazil: implications for conservation and management. Biodiversity and Conservation, vol. 16, no. 4, p. 969-985. http://dx.doi.org/10.1007/s10531006-9036-7.

ALVES, RRN. and ROSA, IL., 2010. Trade of animals used in Brazilian traditional medicine: trends and implications for conservation. Human Ecology, vol. 38, no. 5, p. 691-704. http:// dx.doi.org/10.1007/s10745-010-9352-0.

ALVES, RRN., NOGUEIRA, EEG., ARAUJO, HFP. and BROOKS, SE., 2010. Bird-keeping in the Caatinga, NE Brazil. Human Ecology, vol. 38, no. 1, p. 147-156. http://dx.doi.org/10.1007/ s10745-009-9295-5.

ALVES, RRN., ROSA, IL., LÉONETO, NA. and VOEKS, R., 2012. Animals for the gods: magical and religious faunal use and trade in Brazil. Human Ecology, vol. 40, no. 5, p. 751-780. http:// dx.doi.org/10.1007/s10745-012-9516-1.

ALVES, RRN., LIMA, JRF. and ARAÚJO, HF., 2013. The live bird trade in Brazil and its conservation implications: an overview. Bird Conservation International, vol. 23, no. 1, p. 53-65. http:// dx.doi.org/10.1017/S095927091200010X.

CARRETE, M. and TELLA, JL., 2008. Wild-bird trade and exotic invasions: a new link of conservation concern? Frontiers in Ecology and the Environment, vol. 6, no. 4, p. 207-211. http:// dx.doi.org/10.1890/070075.

DIAS, TLP., LEO NETO, NA. and ALVES, RRN., 2011. Molluscs in the marine curio and souvenir trade in NE Brazil: species composition and implications for their conservation and management. Biodiversity and Conservation, vol. 20, no. 11, p. 2393-2405. http://dx.doi.org/10.1007/s10531-011-9991-5.

ENGEBRETSON, M., 2006. The welfare and suitability of parrots as companion animals: a review. Animal Welfare (South Mimms, England), vol. 15, no. 3, p. 263-276.

Farm Animal Welfare Council - FAWC, 1992. FAWC updates the five freedoms. The Veterinary Record, vol. 131, p. 357.

FERRONATO, BO., MARQUES, TS., GUARDIA, I., LONGO, ALB., PIÑA, CI., BERTOLUCI, J. and VERDADE, LM., 2009. The turtle Trachemys scripta elegans (Testudines, Emydidae) as an invasive species in a polluted stream of southeastern Brazil. Herpetological Bulletin, vol. 109, p. 29-34.

GAMA, TF. and SASSI, R., 2008. Aspectos do comércio ilegal de pássaros silvestres na cidade de João Pessoa, Paraíba, Brasil. Gaia Scientia, vol. 2, no. 2, p. 1-20.

GILARDI, D., 2006. Captured for conservation: will cages save wild birds? A response to Cooney and Jepson James. Oryx, vol. 40, no. 1, p. 24-26. http://dx.doi.org/10.1017/S0030605306000160.

GONÇALVES, MLQ. and REGALADO, LB., 2007. A relação entre o homem e o animal silvestre como uma questão de 
educação ambiental. Fórum Ambiental da Alta Paulista, vol. 3, no. 1, p. 309-330.

GRAHAM, D.L., 1998 Pet birds: historical and modern perspectives on the keeper and the kept. Journal of the American Veterinary Medical Association, vol. 212, no. 8, p. 1216-1219. PMid:9569154.

Instituto Brasileiro do Meio Ambiente e dos Recursos Naturais Renováveis - IBAMA, 2004. Lista dos criadores comerciais. Brasília: IBAMA. Available from: <http://www.ibama.gov.br/ fauna/criadouros/comerciais.pdf $>$. Access in: Jan. 2012.

Instituto Brasileiro do Meio Ambiente e dos Recursos Naturais Renováveis - IBAMA, 2010. Centros de triagem de animais silvestres. Brasília: IBAMA. Available from: <http://www.ibama. gov.br/fauna/cetas.php>. Access in: Jan. 2012.

KUHNEN, VV., REMOR, JO. and MULLER-DE-LIMA, RE., 2012. Breeding and trade of wildlife in Santa Catarina state, Brazil. Revista Brasileira de Biologia = Brazilian Journal of Biology, vol. 72, no. 1, p. 59-64. PMid 22437385. http://dx.doi. org/10.1590/S1519-69842012000100007.

LOPES, JB., CAVALCANTE, RR., ALMEIDA, MM., CARVALHO, MAM., MOURA, SG., DANTAS-FILHO, LA. and CONCEIÇÃO, WLF., 2004. Desempenho de cutias (Dasyprocta prymnolopha) criadas em cativeiro do nascimento até o desmame em Teresina, Piauí. Revista Brasileira de Zootecnia, vol. 33, no. 6, p. 23182322. http://dx.doi.org/10.1590/S1516-35982004000900018.

MORAIS, MM., RUIZ-MIRANDA, CR., GRATIVOL, AD., ANDRADE, CC., LIMA, CAS., MARTINS, A. and BECK, B.,2008. Os sagüis, Callithrix Jacchus e Penicillata, como espécies invasoras na região de ocorrência do Mico-Leão Dourado. In: OLIVEIRA, P.P., GRATIVOL, A.D. and MIRANDA, CRR. (Orgs.). Conservação do mico-leão-dourado: enfrentando os desafios de uma paisagem fragmentada. Rio de Janeiro: Universidade Estadual do Norte Fluminense Darcy Ribeiro. p. 86-117.

NOGUEIRA, SSC., SILVA, MG., DIAS, CTS., POMPÉIA, S., CETRA, M. and NOGUEIRA-FILHO, SLG., 2010. Social behaviour of collared peccaries (Pecari tajacu) under three space allowances. Animal Welfare (South Mimms, England), vol. 19, no. 3 , p. 243-248.

PADRONE, JMB.,2004. O comércio ilegal de animais silvestres: avaliação da questão ambiental no estado do Rio de Janeiro. Rio de Janeiro: Universidade Federal Fluminense. 115 p. Dissertação de Mestrado em Ciência Ambiental.

Rede Nacional de Combate ao Tráfico de Animais Silvestres RENCTAS, 2001. Primeiro relatório nacional sobre o tráfico da fauna silvestre. Brasília: RENCTAS. Available from: <http:// www.renctas.org.br/files/REL_RENCTAS_pt_final.pdf $>$ Access in: March 2012.

ROSA, IL., OLIVEIRA, TPR., OSÓRIO, FM., MORAES, LE., CASTRO, ALC., BARROS, GML. and ALVES, RRN., 2011. Fisheries and trade of seahorses in Brazil: historical perspective, current trends, and future directions. Biodiversity and Conservation, vol. 20, no. 9, p. 1951-1971. http://dx.doi.org/10.1007/s10531011-0068-2. 